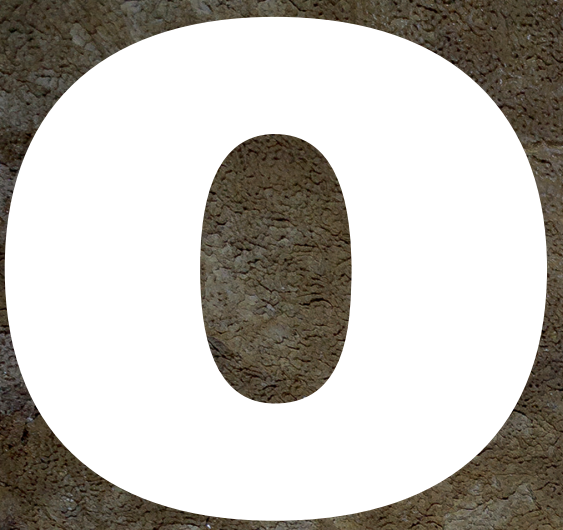

The International Journal of Conservation

Published for

Fauna \& Flora International
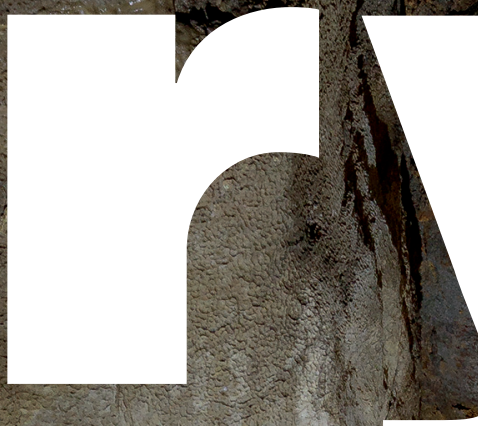

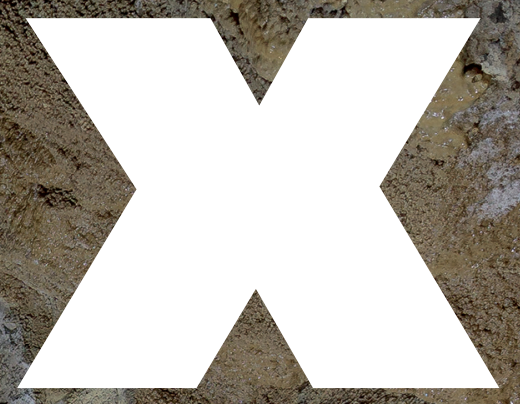

whw ory thejoumalorg
April: 2019 . Volume 53 . Number 2

Invertebrate conservation

Even worms matter

Decline of Asian horseshoe crabs

South-east Asian apple snail

Grazing effects on a grasshopper

\title{
Caterpillar fungus
}

Livelihoods in the Indian Himalaya

Economic dependence in Nepal

Blaming threatened species

Portrayal of human-wildlife conflict

Capacity building for conservation

Problems \& potential solutions

Marco Polo arcali

Persisting in Pakistan?

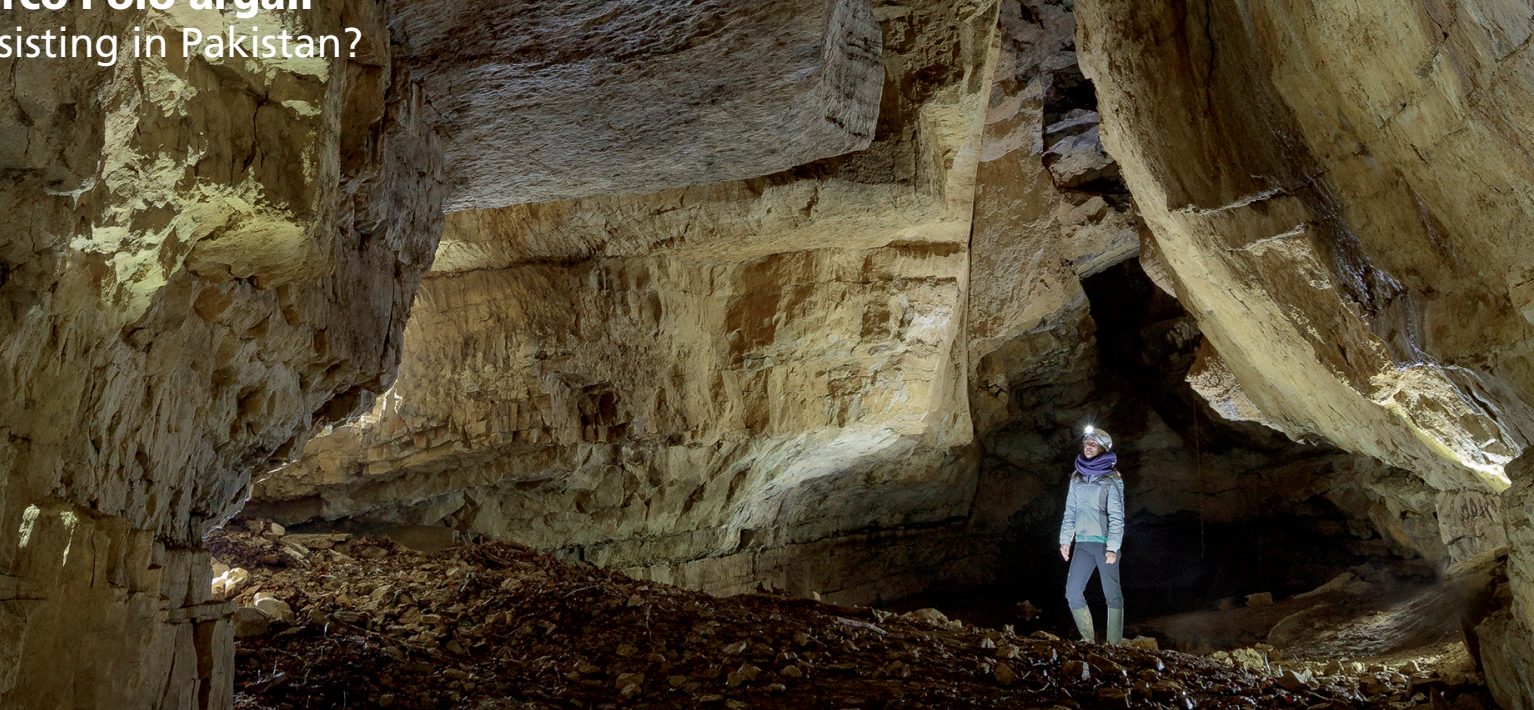


ISSN 0030-6053 Fauna \& Flora International A company limited by guarantee registered in England 2677068 Registered Charity 1011102

A non-profit charitable institution ABN 75132715783 in Australia A non-profit organization EIN \#81-3967095 in the USA

Twitter@FaunaFloraInt @OryxTheJournal
FFI, The David Attenborough Building, Pembroke St,

Cambridge CB2 3QZ, UK

Tel: +44 1223 571000; Fax: +44 1223461481

E-mail info@fauna-flora.org http://www.fauna-flora.org

FFI Australia, PO Box R697, Royal Exchange, NSW 1225, Australia

E-mail ffiaustralia@fauna-flora.org

FFI USA, 1720 N Street NW, Fourth Floor, Washington, D.C. 20036,

USA. E-mail ffiusa@fauna-flora.org

\section{Editor}

Dr Martin Fisher FFI, UK

\section{Managing Editor}

Julia Hochbach FFI, UK

\section{Editorial Assistant}

Emma Muench FFI, UK

\section{Senior Editors}

Professor Bill Adams University of Cambridge, UK Professor Andrew Balmford, FRS University of Cambridge, UK

Dr Porter P. Lowry II Missouri Botanical

Garden, USA and France

Dr Mike Maunder Eden Project, UK

Professor Jeffrey A. McNeely Thailand

Professor E. J. Milner-Gulland University of

Oxford, UK

Dr John G. Robinson Wildlife

Conservation Society, USA

Professor William Sutherland University

of Cambridge, UK

\section{International Board of Editors}

Dr Elizabeth L. Bennett USA

Professor Neil Burgess Denmark

Professor Lisa Campbell USA

Dr Liana Chua UK

Dr Jenny Daltry UK

Dr Aparajita Datta India

Dr Abigail Entwistle UK

Dr Joice Ferreira Brazil

Dr Brendan Fisher USA

Professor Brendan J. Godley UK

Professor Rhys Green UK

Dr George Holmes UK

Professor Zhigang Jiang China

Professor Julia Jones UK

Dr K. Ullas Karanth India

Professor Gustavo Kattan Colombia

Professor Sandra Knapp UK

Ashish Kothari India

Professor Sarah Legge Australia
Dr David Mallon UK

Sara Oldfield, OBE UK

Dr Kent H. Redford USA

Dr Jon Paul Rodriguez Venezuela

Dr Anthony B. Rylands USA

Professor Philip Seddon New Zealand

Dr Noah Sitati Kenya

Dr Bob Smith UK

Dr Paul Smith UK

Professor Rashid Sumaila Canada

Dr Matt Walpole UK

\section{Fauna \& Flora International \\ Patron}

Her Majesty The Queen

President

HRH Princess Laurentien of The Netherlands

\section{Vice Presidents}

Lisel Alamilla

Baroness Amos

Sir David Attenborough, OM, FRS

Professor David Bellamy, OBE

The Lord Browne of Madingley, FR Eng

Lindsay Bury

Charlene de Carvalho-Heineken

Field Marshal Sir John Chapple, GCB, CBE, DL

Viscount Philippe de Spoelberch

Giles Clark

Dame Judi Dench

Dr Lee Durrell

Hugh Fearnley-Whittingstall

Dorette Louise (Dielle) Fleischmann

Stephen Fry

Michael Gollner

Rupert Goodman

Edward Hoare

The Lady Emma Kitchener LVO

Rove McManus

Justin Mundy

Blaine T. Phillips

Dr Lisbet Rausing
Dr Claudio Segré

The Rt Hon Mark Simmonds

Hugh Sloane

Jon L. Stryker

Charles Whitbread

James Wong

The Rt Hon Baroness Young of Old Scone

Jochen Zeitz

\section{Council}

Chair Andrew Sykes

Vice Chair

Professor Nigel Leader-Williams

Treasurer Paul Baldwin

David Gibson

Dr Charlotte Grezo

Andrew Joy

Professor Sandra Knapp

Annette Lanjouw

Mike Maunder

Richard Plackett

Sir Gareth Rhys-Williams

Edward van Cutsem

Diana van de Kamp

Professor Bhaskar Vira

Hugo van Vredenburch

Richard Walker

John Wotton

Chief Executive Officer Mark Rose

\section{US Board of Directors}

President Professor Sandra Knapp

Secretary Diana van de Kamp

Diane Alfano

Dorette Louise (Dielle) Fleischmann

\section{Australian Board of Directors}

Chairman Michael Forsdick

Nick Bubb

Dr Angela Dwyer

Mark Rose
FFI Member Subscription Membership of Fauna \& Flora International starts from $£ 45$ a year for concessions and $£ 85$ for other members (or equivalent price in dollars/euros). For more information about FFI membership visit http://www.fauna-flora.org/membership. Enquiries about back issues for members should be addressed to the Membership Secretary at FFI (members@ fauna-flora.org).

Institutional Subscription Oryx (ISSN 0030-6053) is published four times a year (one volume per annum) in January, April, July, and October. The 2019 subscription price (excluding VAT) of a volume, which includes print and electronic access, is $£ 784.00$ (US $\$ 1411.00$ in USA, Canada and Mexico). The electroniconly price available to institutional subscribers is $£ 622.00$ (US $\$ 1115.00$ in USA, Canada and Mexico).

Orders, which must be accompanied by payment, may be sent to any book seller, subscription agent or direct to the publisher: Cambridge University Press, Journals Fulfillment Department, UPH, Shaftesbury Road, Cambridge CB2 8BS, UK; or in the USA, Canada and Mexico: Journals Fulfillment Department, Cambridge University Press, 1 Liberty Plaza, Floor 20, New York, NY, 10006, USA. EU subscribers (outside the UK) who are not registered for VAT should add VAT at their country's rate. VAT registered members should provide their VAT registration number. Japanese prices for institutions (including ASP delivery) are available from Kinokuniya Company Ltd, P.O. Box 55, Chitose, Tokyo 156, Japan. Prices include delivery by air. Periodicals postage paid at New York, NY, and at additional mailing offices. Postmaster: send address changes in USA, Canada and Mexico to: Oryx, Cambridge University Press, 1 Liberty Plaza, Floor 20, New York, NY, 10006, USA. Claims for missing issues should be made immediately on receipt of the subsequent issues.
Back volumes Copies of the current volume and two previous volumes can be obtained from Cambridge University Press at the above address. Requests for previous volumes should be directed to the Membership Secretary at FFI (members@fauna-flora.org).

Copyright and Permissions This journal is registered with the Copyright Clearance Center, 222 Rosewood Drive, Danvers, MA 01923, USA. Organizations in the USA who are also registered with C.C.C. may therefore photocopy material (beyond the limits permitted by Section 107 and 108 of U.S. Copyright law) subject to payment to C.C.C. of the per-copy fee of $\$ 16.00$. This consent does not extend to multiple copying for promotional or commercial purposes. Code 0030-6053/2017 \$16.00. ISI Tear Sheet Service, 3501 Market Street, Philadelphia, PA 19104, USA, is authorized to supply single photocopies of separate articles for private use only. Organizations authorized by the UK Copyright Licensing Agency may also copy material subject to the usual conditions. For all other use, permission should be sought from Cambridge University Press.

No part of this publication may otherwise be reproduced, stored or distributed by any means without permission in writing from Cambridge University Press, acting for the copyright holder.

Internet Access This journal is included in Cambridge Core, which can be found at: http://cambridge.org/orx. For further information on other Press titles access http://cambridge.org.

This journal issue has been printed on FSC-certified paper and cover board. FSC is an independent, non-government, not-for-profit organization established to promote the responsible management of the world's forests. Please see www.fsc.org for information. 